\title{
逆流防止式尿管膀胱新吻合術の成績と合併症
}

$\begin{array}{ccccc} & \text { 山 } & \text { 田 } & \text { 智 } & \text { 二 } \\ \text { 北海道大学医学部泌沓器科学教室 } & \text { 小 } & \text { 柳 } & \text { 知 } & \text { 彦 } \\ \text { (主任: 过 一郎教授) } & \text { 过 } & & \text { - } & \text { 郎 }\end{array}$

\section{RESULT AND COMPLICATIONS OF ANTI-REFLUX URETERONEOCYSTOSTOMY}

\author{
Tomoji Yamada, Tomohiko Koyanagi and Ichiro Tsuji \\ Department of Urology, Hokkaido University School of Medicine
}

(Director: Prof. I. Tsuji)

In a retrospective study a total of 83 cases (138 ureters) of anti-reflux ureteroneocystostomy performed by us at the Department of Urology, Hokkaido University School of Medicine during a 6-year period from 1971 to 1977 were reviewed.

1) This series comprised 57 cases of primary VUR, 14 cases of non-refluxing megaloureter and 12 cases of other congenital anomalies of the ureter (e.g. ureterocele and ectopic ureter). They consisted of 56 children and 27 adults or 36 males and 47 females.

2) The operation was performed by a modified method of Paquin in 72 cases, by PolitanoLeadbetter's procedure in 9 cases and by other procedures in 2 cases.

3) Therapeutic success was achieved in $92 \%$ of cases, including 76 cases of success with reoperation. The success rate was $96.5 \%$ for primary VUR (including refluxing megaloureter) as against less than $50 \%$ for nonrefluxing megaloureter.

4) In 12 cases the initial operation proved to be unsuccessful. These failures were caused by a stenosis of the anastomosed site in 4 cases by VUR or its recurrence in 8 cases. The latter 8 cases were all children. The incidence of postoperative VUR was particularly high among those infantile cases of megaloureter where the narrowing suture had not been done.

5) Postoperative urinary infection was successfully controlled in 61 of 65 cases. The duration of postoperative chemotherapy in these 61 cases ranged from 1 month to 2 years with an average of 6 months.

6) As postoperative complication a transient pyeloureterectasis occurred in 48 of 71 cases. These changes disappeared spontaneously within 3 months in 20 cases, within 6 months in 26 cases and in 1 year in 2 cases.

7) Contralateral VUR occurred in 7 of 41 cases after unilateral operation. This disorder disappeared spontaneously in 2 to 9 months in 3 of these 7 while persisted in the other 4 . Those cases in which preoperative examination revealed malformation and malposition of the orifice of the contralateral ureter along with abnormalities in pyeloureterogram had a higher incidence of contralateral VUR with a lower frepuency with which VUR disappeared spontaneously.

8) Nineteen of 41 cases undergoing bilateral operation had residual urine and difficulty of urination over a transient postoperative period. These disorders disappeared completely in 1 to 12 months in all cases but one.

9) In 17 of 41 cases treated by Paquin's procedure unilaterally postoperative voiding cystourethrography demonstrated asymmetric vesical contraction, probably due to insufficient contractility of the ipsilateral bladder walls. In 4 cases this bladder deformity was found to disappear in 1 to 3 years postoperatively. 


\section{腥 专}

1952年 Hutch が膀胼尿管逆流 (VUR) の重大性と, その積極的防止手術法を提唱して以来, 逆流防止式尿管 膀脱新吻合術に関しては現在迄多数の報告が相次いでい る. 本法はVUR のみならず megaloureter や尿管瘤等 その他の尿管末端部のいろいろな構造機能異常症例にも 応用され，正しい適応に適正な手技で施行されれば，80 ～90\%以上の例で逆流の防止とともに腎機能の保持改善 と尿路感染除去が期待できるという報告が多い。しかし 実際には手術失敗例や術後合併症も決して少くなく, こ れに関連して手術適応の選定，手術時期の決定あるいは 手術手技の問題点等を種々論議する報告も多数みられ， 今後な招研究を要する事項が多い, 我々は最近 6 年間に 経験した逆流防止式尿管膀胱新吻合術83例の手術成績と 合併症について報告するとともに，以上の諸点に関する 考察と我々の反省事項を述べてみたい。

\section{対象および手術方法}

対象は昭和 46 年 4 月より昭和52年 3 月迄の 6 年間に北 大泌尿器科で这流防止式尿管膀胼新吻合術を行なった 83 例（138尿管）である. 内訳は primary or non-obstructed VUR 57例 (grade II 6 , III36, IV15) の他飞 functionally および mechanically obstructed megaloureter 14例 (以後 megaloureter と略), その他12例 (ureterocele お よび ectopic ureterocele 10例, ectopic ureter 2例) が含まれている（表 1)，性，年龄は表 2 に示したが， 小児例が成人例の約 2 倍を占め, 万ち 1 歳以下の症例は 5 例となっていた。

手術手法は Paquin 変法72例, Politano-Leadbetter 法 9 例，その他 2 例で Paquin 变法が大部分を占めてい

表 1 対象例の内訳（83例，138尿管）

\begin{tabular}{l|c|c}
\hline \multicolumn{1}{c|}{ 症 例 } & 例 数 & 尿管数 \\
\hline primary VUR & 57 & 96 \\
\hline megaloureter & 14 & 16 \\
\hline $\begin{array}{l}\text { ureterocele および } \\
\text { ectopic ureterocele }\end{array}$ & 10 & 23 \\
\hline ectopic ureter & 2 & 3 \\
\hline
\end{tabular}

表 2 対象例の性・年令

\begin{tabular}{l|l|l|l}
\hline & 男 & 女 & 計 \\
\hline 小 児 & 26 & 30 & 56 \\
\hline 成 人 & 10 & 17 & 27 \\
\hline
\end{tabular}

る.な拈我々が行なっている Paquin 変法の詳細は教室 の小柳が既に報告)しているのでここでは割愛する．手 術側は右側 17 , 左側 24 , 両側 $42 て ゙$, 術後経過観察期間は 6 カ月から 6 年で平均 2 年間である.

\section{結 果}

\section{A）手術成績}

術後定期的な IVP および排尿時撮影による追求で VUR がみられず，且つ吻合部狭窄のないものを成功と した。 83例中，初回手術に成功したものは71例（85.6 \%)で，これに再手術成功 5 例を加えると76例（91.6 \%) 飞満足すべき成績を得た。疾患別の成功率は, primary VUR の96.5\%に対し, ureterocele と ectopic ureter では75\%, megaloureter では50\%となつてお り, megaloureter の成績が最も不良であつた.

初回手術失敗12例の内訳は, 吻合部狭窄 4 例と VUR の出現あるいは再現 8 例である. 吻合部狭窄 4 例につい て検討してみると，狭窄の原因は主として手技的なもの で, 小児群と成人群, あるいは払張尿管の絴縮の有無等 による狭窄発現率には特に差はなかつた（表 3)。4例

表 3 吻合部㹨窄 4 例の疾患, 年令, 尿管䋖縮との 関係

\begin{tabular}{|c|c|c|c|c|}
\hline \multirow{2}{*}{1} & \multicolumn{2}{|c|}{ 年 齢 } & \multicolumn{2}{|c|}{ 尿管維縮 } \\
\hline & 小児 & 成人 & $(+)$ & $(-)$ \\
\hline primary VUR & $1 / 39$ & $0 / 20$ & $0 / 5$ & $1 / 54$ \\
\hline megaloureter & $2 / 10$ & $0 / 3$ & $0 / 7$ & $2 / 6$ \\
\hline ureterocele etc. & $0 / 7$ & $1 / 4$ & $1 / 4$ & $0 / 7$ \\
\hline 計 & $3 / 56$ & $1 / 27$ & $1 / 16$ & $3 / 67$ \\
\hline
\end{tabular}

中 3 例に再手術を行ない, いずれる通過障害を除くこと が出来たが，らち 2 例ではVUR が発現した。（再手術 後 VUR 発生の 1 例は 2 回目の再手術で VUR る消失 した）残り 1 例は腎瘦で経過観察中である.なお再手術 を行なつた 3 例の狭窄の原因は, 2 例が尿管膀脱移行部 の角度形成， 1 例は壁内尿管の線維化によるものであつ た。

次に退院後の追求で VUR が出現あるいは再現した 8 例の VUR 再発迄の期間は術後 4 カ月から 3 年 8 カ月で あるが，この失敗の原因る主として技術的なものと考兄 られる.術後 VUR 出現を年龄別にみると，各疾患をと おし成人では 1 例むなく，VUR の出現はすへて小児例 であり（表 4$)$, 特に 3 歳以下では5/17例 $(29.4 \%), 1$ 歳 以下では $2 / 5$ 例 $(40 \%)$ と年歳が小さくなる程 VUR の 
表 4 VUR 再現・出現 8 例の疛患, 年令, 尿管桻 縮との閶倸

\begin{tabular}{c|c|c|c|c}
\hline \multirow{2}{*}{} & \multicolumn{2}{|c|}{ 年 } & \multicolumn{2}{c}{ 尿管艂縮 } \\
\cline { 2 - 5 } & 小少 & 成人 & $(+)$ & $($ (一) \\
\hline primary VUR & $1 / 39$ & $0 / 20$ & $0 / 5$ & $1 / 54$ \\
\hline megaloureter & $5 / 10$ & $0 / 3$ & $1 / 7$ & $4 / 6$ \\
\hline ureterocele etc. & $2 / 7$ & $0 / 4$ & $1 / 4$ & $1 / 7$ \\
\hline 計 & $8 / 56$ & $0 / 27$ & $2 / 16$ & $6 / 67$ \\
\hline
\end{tabular}

再現・発現率が高くなっていた。さらにこの小児 8 例を 疾患別にみてみると，primary VUR では1/39例（2.6\%） に対L, megaloureter 5/10例 $(50 \%)$, ureterocele 等 $2 / 7$ 例 $(28.6 \%)$ となる.㺫ち primary VUR では術後 VUR 再発が特に小児に多いよはいえないが，megaloureter で は成人に比べ小児で明らかにVUR 発現頻度が高かっ た。またVUR の再現・発現率と尿管縫縮 との関係を みてみると，VUR 出現は皮管綘縮を行なつた16例中2 例 $(12.5 \%)$ に対し，水管縫縮を行なわなかった。67例 中 6 例 $(9 \%)$ と全体としては大きな差はないように みえる、たたし将患別にみると，primary VUR および ureterocele 等では疗管綘縮の有無に上るVUR 出現率
に大きな差はないが, megaloureter では術後 VUR 出現 が尿管縫縮を行なつた 7 例中 1 例 $(14.3 \%)$ に対し，尿 管縫縮を行なわなかつた場合は 6 例中 4 例 $(66.7 \%$ ） 高率におよんでおり，megaloureter に対して尿管縫縮を 行なわないと術後 VUR 出現の可能性が極めて高いこと を痛感させられた。VUR の再現・発現した 8 例中 4 例 には主として Politano-Leadbetter 法による再手術を行 ならことにより，3 例で VUR の消失をみたが，1 例は 再びVUR が再発した。なお 4 例の再手術時の検討によ ると，いずれも粘膜卜尿管の短緶あるいは欠如と共に水 管いの開大と，尿管末端部の高度搪張走示していた。

B）爬感染

術後 1 年以上経過した70例のらち，两側 VUR で片侧 のみ手術を行ない対側をそのままにしてある 4 例および 術前より残尿があつた 1 例を除く65例について尿感染の 有無を検讨した。65例中61例に尿感染は制圧されてい た。なおこの61例の+ルファ剤を中心とする術後化学療 法澌间は 1 力月から 2 年で，平均 6 力月となつていた。 水感染が持絽している4 例の内訳はVUR 再現 1 例, 吻 分激狭穹 1 例，㨫側手術後残水存繶 1 例，術前より高度 水腎水我管の㐫る megaloureter 1 例で，最後の例は術

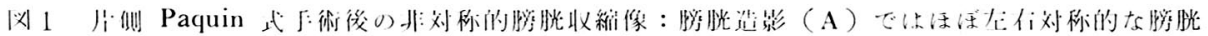

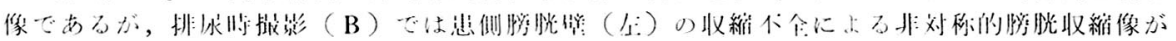

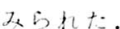
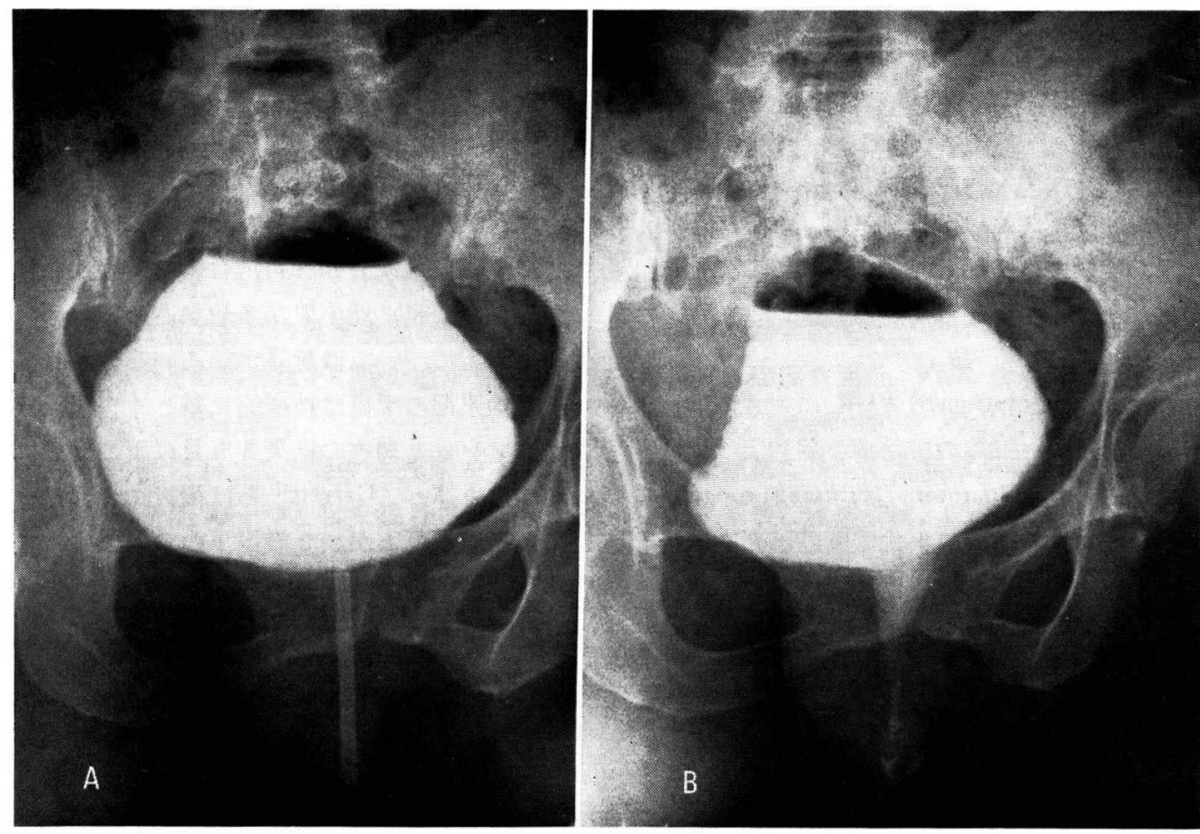
後水腎水尿管は幾分改善したが，IVP 上造影剤の排泄 不良かつ慢性腎㙉腎炎様の変化を呈している症例で品 る.

C) 術後続発合併症

術後の続発合併症として最も多いのは術直後一過性の 腎盂尿管の拡張で, これは初回手術失敗例を除く71例中 48例 $(67.6 \%)$ に術後のIVP で多少とも上部尿路の拡 張像が認められている。ただしいずれもその後自然に消 失するものであり，20例は術後 3 カ月以内に，26例は 6 カ月以内に， 2 例は 1 年で上部尿路昖張の完全な消失を 確認している。

次に片側手術41例の弓ち対側腎盂尿管拡張が現われ たものも 3 例 (7.3\%) あつたが，いずれも 3 カ月以内 に消失した。また対側にVUR が出現したものは7 例

(17.1\%) 西り，らち3 例は $2 \sim 9$ 力月後には自然に消 失したが，4例は10カ月一 2 年後も対側の VUR が存続 している。

一方，両側手術42例のらち術前より残尿の西つた 1 例 を除く41例中，19例（46.3\%）に術後一過性の残尿や排 尿困難が現われ，特に 2 例ではそのためかなりの水尿管 をきたし，吻合部狭窄の出現を疑がつたが，実は多量の 残尿のためであつた。この19例中18例は $1 \sim 12$ カ月で残 尿や排尿困難が消失したが，1例は 1 年後も残尿が持続 している。床扮術式別に両側同時手術後の残尿発现辩を みると, Paquin 変法で18/31例, Politano-Leadbetter 法 で1/8例となり，症例数は少ないが Paquin 変法の方が術 後の残尿発現率が高からた。

また片側 Paquin 式手術41例のうち，術後排俄畤撮影 で闰侧の膀胱壁の収縮不全に上ると照わ机る非対称的な 膀胱収縮像（図 1) を示与ものが17例 (41.5\%) に憄め られている。うち 4 例では $1 \sim 3$ 年後の再検でこの変形 が消失していることが確かめら扎ている。

\section{考按}

最近の primary or non-obstructed VUR に対与る逆流

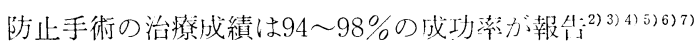
されているが，一方 megaloureter (refluxing megaloureter を含んで）に対する逆流防止:式尔管膀胱新吻合術

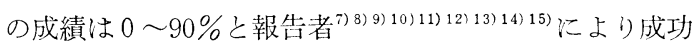
率汇著しい差がある。即ち Derrick ${ }^{8)}$ は手術成功例が 1 例もなかつたことより， megaloureter に対与る逆流 防止式尿管膀胱新吻合術を疑問視しているのに対し， Hendren ${ }^{73)}$ は90\%以上の成功を䛴つており，その他に も最近成功率80 90\%といら報告が散見されているが，
一般にはやはり primary VUR に比べ megaloureter の手術成功率は低くなつている。我々の治療成績で も primary VUR の59例（うちIV度の所謂 refluxing megaloureter 15例をも含む) で96.5\%の成功率を收める ことができたのに対し non-refluxing megaloureter では 成功率が $46.2 \%$ といら不良な結果汇終つたことは大いに 反省させられた。これは我々が megaloureter の小児例 で所謂 narrow segment を切除することにより，上方の 尿管挫張がかなり減少した場合, あえて尿管を縫縮し なかつたためで，この様な非縫縮小児症例汇術後高率に VUR が出現したわけである。

megaloureter t含壳高度桩張尿管の膀胱新吻合が正常 あるい:軽度执張尿管の夫に比へ，手術手技が難しく， 手術成績も覀いことは既に良く知られて㧍り，その原因 あるいは手術手技等については数多く検討されているが いまだ一定した見解はない. Hendren ${ }^{7)}$ は megaloureter の手術が難しい理由に(1) 幼小児が多く,2 既に腎機 能が低下していることが多い. (3) 膀脱壁が肥厚し, 肉 柱形成が著しい（丹尿管の屈曲蛇行が強いため形成手 術を行ならと氺管の血流障害を起こし易いなどと述べて いる。また Johnston ${ }^{9)}$ は搪張尿管壁自体に機能的障害 があることを強調している。我々の泟例でも明らかに高 度抁張尿管症例に手術成績が湎く, 特に non-refluxing

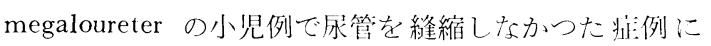
術後高摔にVURが発現した。しかし同じ昖張尿管でも refluxing megaloureter では㽷管縫縮を行なわなからた 症例でもVURの再現は一例もなかつた。ほほ问一交手 術手技で逆流防止式手術を行なつたのにもかかわらず, この様に手術成績が異なるのは年管壁自体の機能的孛る いは機领的障害が異なるためであるっ。

逆流防止式疗管膀胱新吻合術の対俰疾患はいるいるで

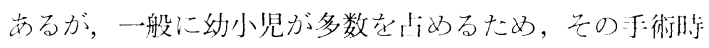
期の決定については意見がいろいろ分かれている。一般 に乳幼児期の于術は技術的に難しく ${ }^{16) 17)}$, Marshall $5^{15 \%}$

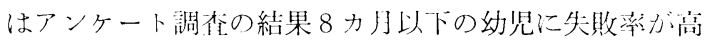

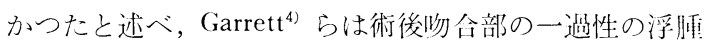
による通過障害が，3歳以下の幼児では永久的な狄窟に 移行し易いとしている。我々の症例でも失敗例の汪之ん ぞは小児例であり, 特に 1 歳以下の高度抁張尿管 5 例 (megaloureter 3 例, ectopic ureterocele 2 例)では術後 吻合部狭窄 2 例, VUR 発現 2 例とほとんどが失敗し再乎: 術が必要となつた。この 5 例はいずれも高度抎张皮管で 腎機能の低下も著名な症例で速かに何等かの手術的操作 
を行なら必要があつたが，この様な乳幼児期症例ではま ず cutaneous ureterostomy or pyelostomy を行なつて腎 尿の排除を計り，乳幼児期には技術的に困難な尿管未端 の形成手術は患児の成長をまつて施行した方がよかつた かもしれない，何れにしても新生・乳幼児期の高度拡張 尿管に対する手術時期の決定打よび手術法の選択は今後 に残された問題である.

逆流防止式尿管膀腅新吻合術後の続発症としては，吻 合部狭窄と VUR 再現・発現の他にもいろいろな合併症 の報告があり，それの防止対策が種々論議されている. この中で比較的多いのは, 片側手術例の 術後対側への VUR 出現で, 文献上10２5\%の頻度と報告 ${ }^{5) 1920202122)}$ されている. Warren ${ }^{22)}$ らは術前の膀脱鏡検查で対倒尿 管口の形あるいは位置異常のあつた症例では術後高率に 対側 VUR が出現し，かつ自然消失することが少いた め,このような症例には術前に対側 VUR がなくても両 側の逆流防止手術を同時に行ならべきであると述べてい る. しかし Parrott $~^{19}$ は術前の尿管口の位置・形態の 異常あるいは IVP 上の腎孟腎杯の変形や尿管停滞の有 無と, 術後の対側 VUR の発現率との間に関係がなく， 術前に対側 VUR の出現を予測することは困難であると 述べている. 我々の症例では片側手術 41 例中 7 例 (17.1 \%) 飞対側 VUR が現われたが，このうち術前に対側尿 管口の位置・形態異常あるいは IVP 上, 腎盂腎杯の異 常が認められた 8 例では 3 例 $(37.5 \%)$ に対し，術前 にこれらの 異常所見が認められなかつた 33 例では 4 例 (12.1\%) 飞術後対側 VURが現われている.さらにこ の 7 例のらち, 術前に尿管口あるいは腎孟腎杯に異常所 見を認めなかつた 4 例中 3 例はその後自然に対側 VUR の消失をみたが，異常所見を認めた 3 例の対側 VUR は すべて現在まで存続していた。すなわち対側 VUR は術 前に対側尿管口あるいは腎孟腎杯に異常所見を認めた症 例に発現率が高く，かつこの場合はとの後の追求で自然 消失する可能性が少ないと思われる。

次に両側手術例の術後に括こる一過性の残尿や排尿 困難の出現は重要な 合併症の一つとして注目されてい

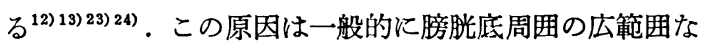
剩離を行なつた時, 膀胱支配神経が損傷され，このため 飞起こる一過性の神経困性膀脂のためと考兄られている

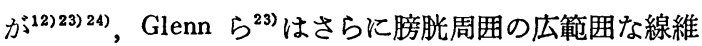
化をむ原因の一つとしてあげている．術後排尿困難・残 尿発生を予防するため, Rawinowitz ら ${ }^{12)}$ は transvesical (Politano-Leadbetter 法) 法を推挙し, Hendren ${ }^{13)}$ は
膀脱周囲（特に hiatus 附近）の剝離をできるだけ少く するため，尿管下端のみを transvesical に剝離する方 法を報告している．我々の経験でも症例数は少ないが Politano-Leadbetter 法の方が両側 Paquin 法よりも術後 残尿・排尿困難の発生率が低かつた，即ち両側手術例で は膀脂周囲の剝離をできるだけ少くする方法を考慮すべ きである。

最後に片側 Paquin 式手術の術後排尿時撮影で，手術 側の膀胼壁の収縮不良と対側膀脂壁の著明な収縮のため と思われる非対称的膀胼収縮像が約半数に認められた が，この特異な所見については従来あまり注目されてい ないようである. Gunterberg ら ${ }^{25)}$ は片側の仙骨神経切断 後の排尿時撮影で, 同側膀胖壁の収縮不良と対側膀胱壁 の著明な収縮がみられると述べており，この片側 Paquin 式手術後の非対称的膀胼收縮像の説明も手術側の膀胱支 配神経障害のためと考えられる。なおこの非対称性収縮 所見も時間と共に消失することが確認されている.

\section{結 語}

昭和 46 年 昭和 52 年の 6 年間に北大泌尿器科で行なつ た逆流防止式尿管膀脱新吻合術83例（138尿管）の成績 および合併症について検討した。

1) 症例は primary VUR 57例, non-refluxing megaloureter 14例, その他 (ureterocele, ectopic ureter な ど）12例で，小児56例，成人 27 例，男36例，女 47 例とな る.

2）術式は Paquin 変法72例, Politano-Leadbetter 法 9 例, その他 2 例であつた.

3）成績は再手術成功例を含め76例，92\%に成功し た. primary VUR (refluxing megaloureter を含む) の 成功率は96.5\%であるのに対し, non-refluxing megaloureter の成功は半数以下にとどまつた.

4）初回手術失敗12例は吻合部狭窄 4 例 と VUR の 再現又は出現 8 例で, VUR 出現 8 例は全例小児例であ り，特に megaloureter の小児例で尿管縫縮を行なわな かつた症例に VUR 発現率が高かつた。

5）術後の尿感染は，65例中61例に制圧されて拉り， この61例の術後化学療法期間は 1 カ月から 2 年で平均 6 カ月となつている.

6）続発合併症として，71例中48例に術後一過性の腎 孟尿管拡張が出現したが，20例は 3 カ月以内， 26 例は 6 カ月以内， 2 例は 1 年で払張は自然に消失した。

7）片側手術41例中 7 例に対側 VUR が出現し，うち 3 例は $2 \sim 9$ カ月で自然消失したが 4 例では存続した。 
術前検査で対側尿管口の形態, 位置の異常および腎孟尿 管像の異常を示するので対側 VUR の出現率が高く, か つこの場合は VUR の自然消失の可能性も少なかつた.

8）両側手術 41 例中19例に術後一過性の残尿や排尿困 難が現われたが，1例以外はすべて1〜12カ月で完全に 消失した。

9) 片側 Paquin 式手術41例中17例に術後排尿時撮影 で同側の膀胱壁の収縮不良によると思われる非対称的膀 脱收縮像がみられた。この特異な変形が術後 $1 \sim 3$ 年で 消失することも 4 例で確認されている。

（本論文の要旨は, 第42回日本泌尿器科学会東部連合 総会において発表した。な技この報告の一部は昭和53年 度科学研究費補助金に上るるのである).

\section{文献}

1) 小柳知彦, 山田智二：膀胱尿管逆流の防止術： Paquin の变法. 臨泌, 31, 501-505, 1977.

2) Brannan, W., Ochsner, M.G., Rosencrantz, D.R., Whitehead, C.M. and Goodier, E.H.: Experiences with vesicoureteral reflux. J. Urol., 109, 46-48, 1973.

3) Scott, J.E.S.: Results of anti-reflux surgery. Lancet, 12, 68-71, 1969.

4) Garrett, R.A. and Schlueter, D.P.: Complications of antireflux operations: Causes and management. J. Urol., 109, 1002-1004, 1973.

5) Scott, J.E.S.: The management of ureteric reflux in children. Brit. J. Urol., 49, 109$118,1977$.

6) Woodard, J.R. and Keats, G.: Ureteral reimplantation: Paquin's procedure after 12 years. J. Urol., 109, 891—894, 1973.

7) Hendren, W.H.: Reoperation for the failed ureteral reimplantation. J. Urol., 111, 403411, 1974.

8) Derrick, F.C.: Management of the large, tortuous, adynamic ureter with reflux. J. Urol., 108, 153-155, 1972.

9) Johnston, J.H. and Farkas, A.: The congenital refluxing megaureter: Experiences with surgical reconstruction. Brit. J. Urol., 47, 153159, 1975.

10) Mclaughlin, A.P., Leadbetter, W.F. and Pfister, R.C.: Reconstructive surgery of primary megaloureter. J. Urol., 106, 186193, 1971.
11) Johnston, J.H.: Reconstructive surgery of megaureter in childhood. Brit. J. Urol., 39, 17-21, 1967.

12) Rabinowitz, R., Barkin, M., Schillinger, J.F., Jeffs, R.D. and Cook, G.T.: Surgical treatment of the massively dilated ureter in children. Part II. Management by primary reconstruction. J. Urol., 118, 436-439, 1977.

13) Hendren, W.H.: Reconstructive urologic surgery, p. 149, Williams \& Wilkins Co., Baltimore, 1977.

14) Williams, D.I. and Hulme-Moir, I.: Primary obstructive mega-ureter. Brit. J. Urol., 42, 140-149, 1970.

15) Bischoff, P.: Operative treatment of megaureter. J. Urol., 85, 268-274, 1961.

16) 过一郎: 小坚泌尿器科の臨床. 改訂第 2 版, P 125，金原出版，東京，1976.

17) Ransley, P.G.: Surgical pediatric urology, p. 259, Georg Thieme Publishers, Stuttgart, 1977.

18) Marshall, S., Guthrie, T., Jeffs, R., Politano, V. and Lyon, R.P.: Ureterovesicoplasty: Selection of patients, incidence and avoidance of complications. A review of 3527 cases. J. Urol., 118, 829-831, 1977.

19) Parrott, T.S. and Woodard, J.R.: Reflux in opposite ureter after successful correction of unilateral vesicoureteral reflux. Urology, 7, 276-278, 1976.

20) Williams, D.I. and Eckstein, H.B.: Surgical treatment of reflux in children. Brit. J. Urol., 37, 13-16, 1965.

21) Thompson, I.M. and Patton, J.F.: Pullthrough ureteral reimplantation for reflux. J. Urol., 105, 631-633, 1971.

22) Warren, M.M., Kelalis, P.P. and Stickler, G.B.: Unilateral ureteroneocystostomy. J. Urol., 107, 466-468, 1972.

23) Glenn, J.F. and Anderson, E.E.: Complications of ureteral reimplantation. Urol. Survey, 23, 243-260, 1973.

24) 辻一郎: 膀腅尿管逆流 (シンポジゥム). 臨 泌, 29, 944-945, 1975.

25) Gunterberg, B., Stener, N.B. and Sundin, T.: Neurourologic evaluation after resection of the sacrum. Invest. Urol., 13, 183-188, 1975.

（1978年12月 4 日受付） 